\title{
The Frequency of Chromosomal Abnormalities and Y Chromosome Microdeletions in Infertile Non-Obstructive Azoospermic and Severe Oligozoospermic Males
}

\author{
Original \\ Article \\ Moheb M. Abdel-Razek', Ezzat S. Elsobky'2, Yousry M. Moustafa MD', Moustafa \\ A. Elsaied ${ }^{1}$, Shreif Refaat ${ }^{1}$ \\ ${ }^{1}$ Andrology Unit, Faculty of Medicine, Mansoura University, Mansoura, Egypt \\ ${ }^{2}$ Department of Pediatrics, Ain Shams University, Cairo, Egypt, ${ }^{3}$ Medical Genetics Center, \\ Cairo, Egypt
}

\begin{abstract}
Purpose: To estimate the frequency and types of both chromosomal abnormalities and Azoospermia Factor (AZF) microdeletions among patients with non-obstructive azoospermia (NOA) and severe oligozoospermia (SOZ) with sperm count less than 5 million/ml.

Methods: Karyotyping was performed for all 1127 patients, whereas AZF microdeletions assay was done for 811 patients including $653 \mathrm{NOA}$ and $158 \mathrm{SOZ}$ by multiplex polymerase chain reaction (PCR). All patients were subjected to clinical examination, scrotal duplex ultrasound and hormonal evaluations.

Results: The frequency of chromosomal abnormalities was $14.4 \%$, higher in NOA than SOZ men (22.6\% versus 3.7\%). Numerical chromosomal abnormalities were higher than structural type (11.8\% versus $2.4 \%)$. Klinefelter syndrome (KS) represented $11.2 \%$ of the total chromosomal and $94.1 \%$ of sex chromosomal abnormalities. AZF microdeletions were higher in NOA than SOZ (6.1\% versus 3.16\%). AZFc microdeletions represented the most frequent finding: $31 / 45$ (68.9\%), followed by AZFbc: 7/45(15.6\%), AZFb: 4/45 (8.8\%) and AZFa: 3/45 (6.7\%). All patients with AZFa (3), AZFb (4) and AZFbc (7) deletions were NOA, while 26/31(83.87\%) with isolated AZFc deletion were NOA and 5/31(16.13\%) were SOZ.

Conclusion: In according to the results shown, we emphasize the importance of karyotyping and AZF microdeletions analysis in such groups. Counseling for such patients before ARTs is warranted to decrease the risk of transmitting genetic abnormalities to off spring.
\end{abstract}

Key Words: AZF, azoospermia, karyotyping, male infertility.

Revised: 22 November 2016, Accepted: 28 January 2017

Corresponding Author: Moustafa Ahmed Elsaied, Tel.: +201019509962, E-mail: maelsaied@mans.edu.eg

ISSN: 2090-6048, June 2017, Vol. 7, No. 2

\section{INTRODUCTION}

Approximately 15 percent of couples are infertile, and among these couples, male factor infertility accounts for approximately 50 percent of the causes ${ }^{[1]}$.

Genetic abnormalities are found in about $5-10 \%$ of oligozoospermic and in $15-20 \%$ of azoospermic cases $^{[2]}$. Including numerical and structural chromosomal abnormalities and AZF microdeletions ${ }^{[3,4]}$.

Klinefelter syndrome (KS) is one of the most common chromosomal abnormalities in humans, occurring in 1:600 males $^{[5]}$.Y chromosome microdeletions are the second most frequent cause of genetic male infertility after KS, grouped in three main regions (AZFa, AZFb and AZFc) on the Yq arm. About $10 \%$ of men with non-obstructive azoospermia (NOA) and 5\% of severely oligozoospermic men (SOZ) show Y chromosome microdeletions ${ }^{[6,7]}$. Few studies evaluated AZF deletions in Egyptian infertile males, however, most of them had few numbers with only azoospermic patients included ${ }^{[8-10]}$.

This work aimed to estimate the frequency of chromosomal abnormalities and AZF microdeletions among Egyptian infertile males with NOA and SOZ.

\section{PATIENTS AND METHODS}

In the period from July, 2011 to June, 2014, a total of 1127 infertile male patients admitted to AndrologyOutpatient Clinic, Mansoura University Hospital, Mansoura, Egypt, were enrolled in this research. They were classified as $653 \mathrm{NOA}$ and $474 \mathrm{SO}$ patients (sperm count less than 5 million $/ \mathrm{ml}$ ). 
Patients with possible etiological factors for male infertility including past or present history of testicular malignancy, radiotherapy or chemotherapy, varicocele, trauma, mumps orchitis, testicular maldescent and orchidectomy were excluded. Obstructive azoospermic patients diagnosed by signs of obstruction (e.g. enlarged or nodular epididymis; nodular, beaded or absent vas), semen analysis (e.g. low semen volume, acidic $\mathrm{pH}$, absent coagulum and low level of semen markers including fructose, alpha-glucosidase and spermatogenic cells) were excluded. Trans-rectal ultrasound (TRU) was performed in case of doubt.

All subjects underwent a comprehensive examination, including a detailed history taking and physical examination. Semen analysis was performed according to WHO laboratory manual for the examination of human semen $(1999)^{[11]}$ on two occasions at 3 weeks interval, following 3- 5 days of sexual abstinence. Azoospermia was verified in at least 3 ejaculates from each patient by pellet analysis after semen centrifugation (3000 rpm for 15 minutes).

All patients underwent a scrotal color duplex examination to evaluate testicular volume, scrotal contents and varicocele. Testicular volume was determined using 7.5-MHz transducers (Medison Sonoace X8, Samsung Medison Co, Ltd, Seoul, Korea). The ultrasonographic testicular volumes were calculated as the length $\times$ width $\times$ depth $\times 0.71^{[12]}$

All patients underwent hormonal evaluation of follicle stimulating hormone (FSH), luteinizing hormone (LH), prolactin (PRL), total testosterone (T) and estradiol (E2) using a chemiluminescent immunoassay system (Immulite 1000; Siemens Medical Solutions and Diagnostics, Los Angeles, California). Assessment of free testosterone was done for KS patients (127) by (Stat Fax303 Plus, USA) ELISA reader, using Diagnostics Biochem Canada (DBC) Kit. Normal ranges were as follows; $\mathrm{FSH}=0.7-11.1$ $\mathrm{mIU} / \mathrm{ml}$; $\mathrm{LH}=0.8-7.6 \mathrm{mIU} / \mathrm{ml}$; Prolactin $=2.5-17 \mathrm{ng} / \mathrm{ml}$; Testosterone $($ total $)=2451600-\mathrm{ng} / \mathrm{dl}$; Testosterone $($ free $)$ $=9.3-26.5 \mathrm{pg} / \mathrm{ml}$; Estradiol $=0.0-56 \mathrm{pg} / \mathrm{ml}$.

Chromosomal analysis was performed in all 1127 cases. All samples were subjected to phytohemagglutininstimulated whole blood culture in RPMI-1640 media according to standard procedures. Twenty G-banded metaphases were analyzed from each patient. However, in case of mosaicism or presence of any abnormal cell among previous 20 metaphases was suspected, the number was increased to 30 then up to 50 metaphases to confirm the abnormality. Chromosomes were arranged and prepared for analysis according to the international system for human cytogenetic Nomenclature (ISCN) ${ }^{[13]}$.

AZF microdeletions were done for 811 patients (653 NOA and 158 SOZ patients). Genomic DNA was obtained from peripheral blood leukocytes. Microdeletions of the $\mathrm{Y}$ chromosome were screened by multiplex polymerase chain reaction (PCR) using Wizard genomic DNA purification kit (\#A1120, Promega Corporation, Madison, WI, USA) according to the manufacturer's protocol. The European Academy of andrology and the European Molecular Genetics Quality Network (EAA/ EMQN) guidelines recommend the use of six STS loci (sY84, sY86, sY127, sY134, sY254, sY255) to detect up to $95 \%$ of all reported Y-chromosome microdeletions in the AZF regions. Additional STS loci can then be used to define the deletion breakpoints further ${ }^{[14]}$.

Multiple PCR amplifications of 25 loci covering AZFa, $\mathrm{AZFb}, \mathrm{AZF}$ regions on Y-chromosome were used. The following loci were screened: $Z F Y$ in the PAR region; SY81, SY86, SY84, DFFRY, SY182 in the AZFa region; SY1235, SY113, SY118, SY127, SY130, SY134, SY143 in the AZFb region; SY1161, SY145, SY148, SY1291, SY152, SY153, SY254, SY255, SY157, SY158 in the AZFc region; and SY160 in the Yq12 heterochromatic region. The SRY gene (testis-determining factor on the short arm of the Y chromosome) was included in the analysis as an internal control for the presence of Y-specific AZF sequences.

Multiplex fluorescent PCR primer mix included PCR mix with buffer, dNTP and $\mathrm{MgCl} 2$, Taq polymerase, $30 \mathrm{ng}$ DNA sample, and $\mathrm{H} 2 \mathrm{O}$ in a final volume of $25 \mu \mathrm{l}$. The PCR program was set at $95^{\circ} \mathrm{C}$ for $10 \mathrm{~min}$, followed by 35 cycles at $94^{\circ} \mathrm{C}$ for $60 \mathrm{sec}, 60^{\circ} \mathrm{C}$ for $60 \mathrm{sec}$, and $72^{\circ} \mathrm{C}$ for $60 \mathrm{sec}$, thereafter one cycle of $45 \mathrm{~min}$ at $65^{\circ} \mathrm{C}$ for final extension. In each reaction, one sample of fertile male genomic DNA as positive, one sample of female DNA and one sample of distilled water without DNA were used as controls for each set of primers. After amplification, PCR products were subjected to capillary electrophoresis on genetic analyzer (thermal cycler). A STS was considered absent only after at least two amplifications failure in the presence of successful amplification of control (SRYsY14). The study was approved by the Research Ethics Committee (REC) for experimental and clinical studies at Faculty of Medicine, Mansoura University, Mansoura, Egypt. The importance of the study was explained to all participants and an informed written consent was obtained from all subjects before performing the study. The study was conducted according to the Declaration of Helsinki Principles.

Statistical analysis was performed using Statistical Package for the Social Sciences (SPSS, Chicago, Illinois) for Windows 17.00. The parametric data were expressed as mean, and standard deviation. The nonparametric data were expressed as median, and range. Mann-Whitney test was used as a test of significance for comparison of two groups. The qualitative data were presented in the form of number and percentage. Spearman rank correlation 
coefficient was used for evaluation of correlations between variables. Multiple stepwise logistic regression was used to determine the most significant predictors for AZF microdeletions. Differences were considered statistically significant at $P$ value $<0.05$.

\section{RESULTS}

This study included 1127 infertile male; 653 (57.9\%) NOA and 474 (42.1\%) SOZ patients. Left and right testicular volume were significantly lower in NOA than SOZ. NOA patients showed significantly higher FSH and LH and significantly lower total testosterone than SOZ patients (Table 1)

The frequency of chromosomal abnormalities was $162 / 1127(14.4 \%)$, higher in NOA than in SOZ men $(22.6 \%$ versus $3.7 \%$ respectively). Numerical chromosomal abnormalities were higher than structural type $(11.8 \%)$ versus $2.4 \%)$. KS represented $11.2 \%$ (127 /1127) of the total chromosomal and 94.1\% $(127 / 135)$ of sex chromosomal abnormalities. Chromosomal translocations were found in $20 / 1127$ (1.8\%), chromosomal inversions $646,(0.5 \%)$ 1127/XX male $547,(0.4 \%)$ 1127/XYY 2/ 1127 (0.2\%) and marker chromosome $2 / 1127$ (0.2\%).

The frequency of sex chromosomal abnormalities was higher than autosomal type $(11.9 \%$ versus $1.8 \%)$, higher in NOA than SOZ (20.5\% versus $0.2 \%$ ), while the autosomal abnormalities were higher in SOZ than NOA (2.9\% versus $1.1 \%$, respectively). Chromosomal translocation was the most frequent autosomal abnormality, 16/ 21(76.1\%) (Table 2).

Left and right testicular volumes were significantly higher in patients with normal karyotype, 46, XY (965) than those with abnormal karyotype (162).

Patients with abnormal karyotype showed lower total $\mathrm{T}$ and higher FSH and LH than those with normal karyotype (Table 3 ).

AZF microdeletions were the most common genetic abnormality after KS (5.5\% versus $11.2 \%$, respectively). AZF microdeletions were higher in NOA than in SOZ (6.1\% versus $3.16 \%$, respectively). AZFc microdeletions represented the most frequent finding, 31/ 45 (68.9\%), followed by AZFbc, 7/ 45(15.6\%), AZFb, 4 /45 (8.8\%) and AZFa, $3 / 45$ (6.7\%). All patients with AZFa (3), $\mathrm{AZFb}$ (4) and AZFbc (7) deletions were NOA, while $26 / 31(83.87 \%)$ with isolated AZFc deletion were NOA and $5 / 31(16.13 \%$ ) were SOZ (Table 4$)$.

Testicular volume was lower but not statistically significant in patients with AZF microdeletions than those without. Patients with AZF microdeletions showed statistically significant higher serum FSH and LH than those without microdeletions (Table 5).

Using multiple stepwise logistic regression, age, duration of infertility, sperm count, serum FSH, LH, PRL, T and E2, left and right testicular volumes could not predict either karyotype abnormality or AZF microdeletion (Table 6 and 7 respectively).

Table 1: Patients' characteristics and the results of testicular volume and hormonal analyses.

\begin{tabular}{|c|c|c|c|}
\hline $\begin{array}{l}\text { Group } \\
\text { (Number) }\end{array}$ & $\begin{array}{l}\text { NOA } \\
(653)\end{array}$ & $\begin{array}{c}\text { SO } \\
(474)\end{array}$ & $\mathrm{P}$ \\
\hline $\begin{array}{l}\text { Age (years) } \\
\text { mean } \pm \mathrm{SD} \\
\text { range }\end{array}$ & $\begin{array}{c}31.44 \pm 6.43 \\
(20.00-55.00)\end{array}$ & $\begin{array}{c}29.97 \pm 4.95 \\
(20.00-50.00)\end{array}$ & $<0.001$ \\
\hline Duration of infertility (years) & $\begin{array}{c}4.26 \pm 4.50 \\
(1.00-25.00)\end{array}$ & $\begin{array}{c}2.86 \pm 2.44 \\
(1.00-15.00)\end{array}$ & $<0.001$ \\
\hline Lt. testis volume $(\mathrm{cm} 3)$ & $\begin{array}{c}7.42 \pm 4.74 \\
(0.25-20.00)\end{array}$ & $\begin{array}{c}12.94 \pm 3.01 \\
(4.00-19.00)\end{array}$ & $<0.001$ \\
\hline Rt. testis volume $(\mathrm{cm} 3)$ & $\begin{array}{c}8.13 \pm 4.88 \\
(0.50-21.00)\end{array}$ & $\begin{array}{c}13.76 \pm 3.01 \\
(5.00-20.00)\end{array}$ & $<0.001$ \\
\hline
\end{tabular}




\begin{tabular}{lccc} 
FSH $(\mathrm{mIU} / \mathrm{ml})$ & $18.41 \pm 14.46$ & $7.62 \pm 6.42$ & $(0.90-39.00)$ \\
& $(1.00-77.00)$ & $5.86 \pm 3.21$ & $(1.00-32.00)$ \\
$\mathrm{LH}(\mathrm{mIU} / \mathrm{ml})$ & $9.85 \pm 6.91$ & $11.13 \pm 5.96$ & $(2.00-29.00)$ \\
& $(0.60-49.00)$ & & 0.155 \\
PRL $(\mathrm{ng} / \mathrm{ml})$ & $10.58 \pm 6.75$ & $500.22 \pm 211.06$ \\
& $(2.00-82.00)$ & $(137.00-996.00)$ \\
Total T(ng/dl) & $387.64 \pm 196.87$ & $26.38 \pm 14.20$ \\
& $(17.00-987.00)$ & $(4.60-93.00)$ \\
\hline
\end{tabular}

Table 2: Numerical and structural chromosomal results of the studied patients

\begin{tabular}{|c|c|c|c|}
\hline & 1 findings & NOA (653) & SOZ (474) \\
\hline Normal & Normal 46,XY & $495 / 653(75.8 \%)$ & $456 / 474(96.2 \%)$ \\
\hline \multirow{4}{*}{$\begin{array}{l}\text { Numerical } \\
\text { abnormalities }\end{array}$} & Klinefelter (KS) 47,XXY & $118 / 653(18.1 \%)$ & $0 / 474(0.0 \%)$ \\
\hline & Mosaic(KS) 47,XXY/46,XY & $9 / 653(1.3 \%)$ & $0 / 474(0.0 \%)$ \\
\hline & 47,XYY & $1 / 653(0.1 \%)$ & $1 / 474(0.2 \%)$ \\
\hline & Total & $128 / 653(19.6 \%)$ & $1 / 474(0.2 \%)$ \\
\hline \multirow{5}{*}{$\begin{array}{l}\text { Structural } \\
\text { abnormalities }\end{array}$} & $46, X X$ & $5 / 653(0.7 \%)$ & $0 / 474(0.0 \%)$ \\
\hline & Inversion & $4 / 653(0.6 \%)$ & $2 / 474(0.4 \%)$ \\
\hline & Translocation & $7 / 653(1.1 \%)$ & $13 / 474(2.7 \%)$ \\
\hline & Marker chromosome & $0 / 653(0.0 \%)$ & $2 / 474(0.4 \%)$ \\
\hline & Total & $16 / 653(2.5 \%)$ & $17 / 474(3.5 \%)$ \\
\hline Total & & $144 / 653(22.1 \%)$ & $18 / 474(3.7 \%)$ \\
\hline
\end{tabular}


Table 3: Comparison of patients according to the karyotyping

\begin{tabular}{|c|c|c|c|}
\hline Group & $\begin{array}{c}\text { Normal karyotype (965) } \\
\text { Mean } \pm \mathrm{SD} \\
\text { Range }\end{array}$ & $\begin{array}{c}\text { Abnormal karyotype } \\
\text { Mean } \pm \text { SD } \\
\text { Range }\end{array}$ & $\mathrm{P}$ \\
\hline Lt. testis volume $(\mathrm{cm} 3)$ & $\begin{array}{c}10.91 \pm 4.14 \\
(2.00-20.00)\end{array}$ & $\begin{array}{c}2.90 \pm 3.66 \\
(0.25-13.00)\end{array}$ & $<0.001^{*}$ \\
\hline Rt. testis volume (cm3) & $\begin{array}{c}11.70 \pm 4.21 \\
(2.00-21.00)\end{array}$ & $\begin{array}{c}3.47 \pm 3.80 \\
(0.50-15.00)\end{array}$ & $<0.001^{*}$ \\
\hline $\mathrm{FSH}(\mathrm{mIU} / \mathrm{ml})$ & $\begin{array}{l}10.91 \pm 9.970 \\
(0.90-59.00)\end{array}$ & $\begin{array}{l}28.27 \pm 15.66 \\
(2.00-77.00)\end{array}$ & $<0.001 *$ \\
\hline $\mathrm{LH}(\mathrm{mIU} / \mathrm{ml})$ & $\begin{array}{c}6.79 \pm 4.42 \\
(1.00-47.00)\end{array}$ & $\begin{array}{c}16.44 \pm 8.62 \\
(2.00-49.00)\end{array}$ & $<0.001^{*}$ \\
\hline Prolactin(ng/ml) & $\begin{array}{c}10.94 \pm 6.30 \\
(2.00-82.00)\end{array}$ & $\begin{array}{c}9.96 \pm 6.98 \\
(2.00-44.00)\end{array}$ & 0.066 \\
\hline Total T (ng/dl) & $\begin{array}{c}460.88 \pm 204.04 \\
(17.00-996.00)\end{array}$ & $\begin{array}{l}277.17 \pm 154.35 \\
(41.00-968.00)\end{array}$ & $<0.001 *$ \\
\hline $\mathrm{E} 2(\mathrm{pg} / \mathrm{ml})$ & $\begin{array}{c}25.84 \pm 19.669 \\
(3.00-480.00) \\
\end{array}$ & $\begin{array}{c}27.11 \pm 17.44 \\
(1.00-139.00) \\
\end{array}$ & 0.510 \\
\hline
\end{tabular}

Table 4: AZF microdeletions among studied patients

\begin{tabular}{|c|c|c|c|}
\hline Type & $\begin{array}{l}\text { NOA } \\
(653)\end{array}$ & $\begin{array}{c}\mathrm{SOZ} \\
(158)\end{array}$ & $\begin{array}{l}\text { Total } \\
\text { (811) }\end{array}$ \\
\hline Normal AZF & $613 / 653(93.8 \%)$ & $153 / 158(96.9 \%)$ & 766/811 (94.4\%) \\
\hline AZF a deletions & $3 / 653(0.4 \%)$ & $3 / 653(0.4 \%)$ & $3 / 811(0.4 \%)$ \\
\hline AZF b deletions & $4 / 653(0.6 \%)$ & $0 / 158(0.0 \%)$ & $4 / 811(0.5 \%)$ \\
\hline AZF c deletions & $26 / 653(3.9 \%)$ & $5 / 158(3.16 \%)$ & $31 / 811(3.8 \%)$ \\
\hline AZF bc deletions & $7 / 653(1.07 \%)$ & $0 / 158(0.0 \%)$ & $7 / 811(0.9 \%)$ \\
\hline Total AZF deletions & $40 / 653(6.1 \%)$ & $5 / 158(3.16 \%)$ & $45 / 811(5.5 \%)$ \\
\hline
\end{tabular}


Table 5: Comparison of patients according to AZF microdeletions

\begin{tabular}{|c|c|c|c|}
\hline Group & Normal (766) & AZF microdeletion (45) & $\mathrm{P}$ \\
\hline Age (year) & $31.15 \pm 6.25(20.00-55.00)$ & $30.16 \pm 5.54(23.00-47.00)$ & 0.385 \\
\hline Lt. testis volume $(\mathrm{cm} 3)$ & $8.65 \pm 1.68(7.00-13.00)$ & $8.44 \pm 5.03(0.25-20.00)$ & 0.495 \\
\hline Rt. Testis volume $(\mathrm{cm} 3)$ & $9.58 \pm 1.82(7.00-14.00)$ & $9.18 \pm 5.17(0.50-21.00)$ & 0.246 \\
\hline Semen volume(mlL) & $2.74 \pm 0.96(2.00-5.00)$ & $1.68 \pm 0.71(0.10-7.00)$ & 0.730 \\
\hline Sperm count (million/ml) & $0.34 \pm 0-.74(0.00-4.00)$ & $0.23 \pm 0.55(0.00-1.90)$ & 0.429 \\
\hline FSH (mIU/ml ) & $13.13 \pm 6.97(1.00-29.00)$ & $16.71 \pm 14.11(1.00-77.00)$ & $0.011^{*}$ \\
\hline $\mathrm{LH}(\mathrm{mIU} / \mathrm{ml})$ & $7.29 \pm 3.61(1.00-19.00)$ & $9.22 \pm 6.65(0.60-49.00)$ & $0.004 *$ \\
\hline $\begin{array}{c}\text { Prolactin } \\
(\mathrm{ng} / \mathrm{ml})\end{array}$ & $10.69 \pm 6.58(2.00-82.00)$ & $10.42 \pm 5.71(3.00-22.00)$ & 0.842 \\
\hline Total T (ng/dl) & $433.48 \pm 211.49(146.0-985.0)$ & $418.37 \pm 210.31(17.00-996.00)$ & 0.659 \\
\hline $\mathrm{E} 2(\mathrm{pg} / \mathrm{ml})$ & $26.45 \pm 22.16(1.00-480.00)$ & $24.39 \pm 11.64(11.00-59.00)$ & 0.605 \\
\hline
\end{tabular}

Table 6: Multiple stepwise logistic regression analysis of different variables to predict karyotype abnormality.

\begin{tabular}{|c|c|c|c|c|c|}
\hline \multirow{2}{*}{ Predictor } & \multirow{2}{*}{ B } & \multirow{2}{*}{$\operatorname{Exp}(B)$} & \multicolumn{2}{|c|}{$95.0 \%$ CI for EXP(B) } & \multirow{2}{*}{$\mathrm{P}$} \\
\hline & & & Lower & Upper & \\
\hline Age (year) & -0.022 & 0.979 & 0.925 & 1.035 & 0.448 \\
\hline $\begin{array}{l}\text { Duration of marriage } \\
\text { (year) }\end{array}$ & -0.010 & 0.990 & 0.916 & 1.070 & 0.794 \\
\hline Semen volume (mlL) & -0.024 & 0.966 & 0.897 & 1.051 & 0.561 \\
\hline $\begin{array}{l}\text { Semen count } \\
(\text { million/mlL) }\end{array}$ & -0.438 & 0.684 & 0.314 & 1.032 & 0.163 \\
\hline FSH $(\mathrm{mIU} / \mathrm{ml})$ & -0.002 & 0.992 & 0.871 & 1.013 & 0.745 \\
\hline LH (mIU/ml ) & -0.115 & 0.871 & 0.659 & 1.307 & 0.431 \\
\hline
\end{tabular}




\begin{tabular}{|c|c|c|c|c|c|}
\hline PRL (ng/ml) & -0.010 & 0.990 & 0.951 & 1.030 & 0.612 \\
\hline Total T ( ng/dl) & -0.029 & 0.972 & 0.871 & 1.108 & 0.760 \\
\hline $\mathrm{E} 2(\mathrm{pg} / \mathrm{ml})$ & 0.006 & 1.006 & 0.997 & 1.014 & 0.182 \\
\hline $\begin{array}{l}\text { Lt. Testis } \\
\text { volume }\left(\mathrm{cm}^{3}\right)\end{array}$ & -0.310 & 0.733 & 0.461 & 1.167 & 0.191 \\
\hline $\begin{array}{l}\text { Rt. Testis } \\
\text { volume }\left(\mathrm{cm}^{3}\right)\end{array}$ & -0.216 & 0.805 & 0.514 & 1.262 & 0.345 \\
\hline
\end{tabular}

B: B coefficient; Exp (B): exponential B; CI =Confident interval

Table 7: Multiple stepwise logistic regression analysis of different variables to predict AZF microdeletion.

\begin{tabular}{|c|c|c|c|c|c|}
\hline \multirow{2}{*}{ Predictor } & \multirow{2}{*}{ B } & \multirow{2}{*}{$\operatorname{Exp}(B)$} & \multicolumn{2}{|c|}{$95.0 \% \mathrm{CI}$ for $\operatorname{EXP}(\mathrm{B})$} & \multirow{2}{*}{$\mathrm{P}$} \\
\hline & & & Lower & Upper & \\
\hline Age (year) & -0.025 & 0.976 & 0.898 & 1.060 & 0.562 \\
\hline $\begin{array}{l}\text { Duration of marriage } \\
\text { (year) }\end{array}$ & -0.019 & 0.981 & 0.860 & 1.118 & 0.771 \\
\hline Semen volume (mlL) & -0.127 & 0.880 & 0.637 & 1.217 & 0.440 \\
\hline $\begin{array}{ll}\text { Semen } & \text { count } \\
(\text { million } / \mathrm{mlL}) & \end{array}$ & -0.236 & 0.789 & 0.415 & 1.501 & 0.471 \\
\hline $\mathrm{FSH}(\mathrm{mIU} / \mathrm{ml})$ & -0.033 & 0.967 & 0.911 & 1.026 & 0.269 \\
\hline $\mathrm{LH}(\mathrm{mIU} / \mathrm{ml})$ & -0.002 & 0.998 & 0.893 & 1.115 & 0.969 \\
\hline PRL ( ng/ml) & -0.013 & 0.987 & 0.929 & 1.049 & 0.669 \\
\hline Total $\mathrm{T}(\mathrm{ng} / \mathrm{dl})$ & 0.000 & 1.000 & 0.998 & 1.002 & 0.910 \\
\hline $\mathrm{E} 2(\mathrm{pg} / \mathrm{ml})$ & -0.003 & 0.997 & 0.972 & 1.024 & 0.846 \\
\hline $\begin{array}{l}\text { Lt. Testis volume } \\
\left(\mathrm{cm}^{3}\right)\end{array}$ & -0.538 & 0.584 & 0.324 & 1.051 & 0.173 \\
\hline $\begin{array}{l}\text { Rt. Testis volume } \\
\left(\mathrm{cm}^{3}\right)\end{array}$ & 0.395 & 1.485 & 0.839 & 2.627 & 0.175 \\
\hline
\end{tabular}

B: B coefficient; Exp (B): exponential B; CI =Confident interval 


\section{DISCUSSION}

The frequency of chromosomal abnormalities, in our study, was $14.4 \%$, higher in NOA than in SOZ men $(22.1 \%$ versus $3.8 \%$, respectively). These results were comparable to the previously reported range of $2.02-22.2 \%$ for infertile men $^{[2,4,15-18,19-36]}$.

The lower frequency $(2.02 \%)$ reported by Clementini et al. ${ }^{[19]}$ was due to the heterogeneity of their studied patients and inclusion of mild oligozoospermic with sperm count ranging from five to $20 \mathrm{million} / \mathrm{ml}$. while Dada et al..$^{[2]}$ reported higher frequency $(22.2 \%)$ by including only azoospermic and severe oligozoospermic (sperm count less than 5 million $/ \mathrm{ml}$ ). The higher frequency of chromosomal abnormalities in our NOA than SOZ men $(22.6 \%$ versus $3.7 \%$, respectively) was in agreement with the results of other studies suggesting that the prevalence of chromosomal abnormalities increases as the sperm count decreases ${ }^{[18,20,21,23,25,32,35,37]}$.

In our research, Tthe frequency of numerical chromosomal abnormalities in our study iwas higher than the structural type $(11.8 \%$ versus $2.4 \%$ ). Several studies ${ }^{[4,20,28,31,33,38,39]}$ reported similar result ${ }^{[4,20,28,31,33,38,39]}$. However, in other studies, the frequency of structural abnormalities was higher than numerical ones ${ }^{[18,32]}$. These differences might be due to ethnic differences, different patient selection criteria and methodological aspects.

The sex chromosome abnormalities are higher in men with NOA than SOZ $(20.5 \%$ versus $0.2 \%$, respectively), while the autosomal abnormalities are higher in men with SOZ than NOA $(2.9 \%$ versus $1.1 \%$, respectively) as shown in (Table 2). These results supports the previous notion that sex chromosome abnormalities are more frequent in men with azoospermia, while autosomal abnormalities are more frequent in oligozoospermic men ${ }^{[25,32,35,37,40-42]}$. $\mathrm{KS}$ is the most frequent sex chromosome abnormality among our patients, $127 / 135(94.1 \%)$, and this is in accordance with other studies ${ }^{[4,18,23,33,34,43,44]}$.

Chromosomal translocations are the most frequent autosomal abnormality, 16/ 21(76.1\%), which is in agreement with many studies ${ }^{[34,37,45]}$.

The autosomal abnormalities were $3.5 \%$ compared with $0.42 \%$ of people within the general population. In addition, infertile males were reported to have rearrangements of sex chromosomes by karyotyping of $1.7 \%$, compared with $0.10 \%$ among the general male population ${ }^{[46]}$.

After KS, AZF microdeletions in this study is are the most common genetic abnormality (5.5\%) among our study groups after KS (11.2\%), (Table 4). This result is within the previously reported range of $0.98 \%$ to $55.5 \%$ for infertile men in several studies $^{[4,14,24,25,27,28,31,34,47-61]}$.

The low frequency of AZF microdeletions (0.98\%) reported by Van der Ven et al. ${ }^{[47]}$ was due to the heterogeneity of the studied patients and together with inclusion of mild oligozoospermic (sperm count from 5 to 20 million $/ \mathrm{ml}$ ) and severe teratozoospermic patients with sperm counts $>20$ million $/ \mathrm{ml}$. The higher frequency $(55.5 \%)$ reported by Foresta et al. ${ }^{[62]}$ might be attributed to inclusion of only azoospermic patients with Sertoli cell only in their testicular histology and the low number of studied patients.

In this study, the frequencies of AZF microdeletions were $6.1 \%(40 / 653)$ and $3.16 \%(5158 /)$ in NOA and SOZ, respectively shown in, (Ttable 4). These results are within the previously reported in several studies, whereas the range of $2.13-15.00 \%$ reported for men with NOA and $0.00-13.1 \%$ for SOZ in several studies $^{[24,25,27,31,49,52,54,55,59,61,63]}$. and withBesides, the European Association of Urology Guidelines on Male Infertility (The 2012 update) who reported that azoospermic men had the highest frequency of classical Y microdeletions ( $8-12 \%$ ) followed by those with oligozoospermia $(3-7 \%)^{[64]}$.

This wide range of deletion frequency might be due to ethnic differences, different patient selection criteria and methodological aspects including the type and number of markers used.

This study foundOur research revealed no significant difference in the frequency of AZF deletions between the NOA and the SOZ groups $(6.1 \%$ versus $3.16 \%, P=0.145$ ) as in (Ttable 4 , consistent with). This result is in agreement with $\mathrm{Ng}$ et al. ${ }^{[25]}$ who reported no significant difference ( $8.5 \%$ versus $8.2 \%$ ). HoweverOn the other hand, Kumtepe et al. [24] and Ambulkar et al. ${ }^{[61]}$ reported a significant difference in the frequency of AZF deletions between the NOA and SOZ groups $(9.51 \%$ versus $1.86 \%)$ and $(13.1 \%$ versus $5.2 \%$, respectively).

AZFc deletion in our study is the predominant type of Y-microdeletions ( $31 / 45=68.8 \%$ ) in our research (Table 4). It represents 66\% (2640/) of AZF deletions in NOA and 100\% (55/) in SOZ. This result is comparable to the previously reported range (46.687.1\%-) for AZFc deletion in several studies from different populations ${ }^{[9,24,25,51,53,55,57,65]}$. In contrast to these studiesHowever, Mafra et al. ${ }^{[28]}$ reported no AZFc deletions in their Brazilian NOA men.

In this study, the AZFc deletion frequency was represents $68.8 \%(31 / 45)$ followed by the AZFbc 
region 15.5\% (7/ 45), AZFb 8.8\% (4/ 45) and AZFa $6.6 \%(3 / 45)$ illustrated in (Table 4,). These results which were similar to other studies ${ }^{[8,9,30,55]}$. On the other hand, Mohamed et al. ${ }^{[20]}$ found that the AZFbc combination regions was the most frequently deleted regions $(5,71.4 \%)$ followed by $\operatorname{AZFc}(2,26.8 \%)$ with no separate microdeletions in either $\mathrm{AZFb}$ and/or AZFa in their Kuwaiti infertile males from Kuwait. In addition, Saeed et al.$^{[10]}$ found that AZFbc (22/7 4, $28.37 \%$ ) to beas the most frequently deleted regions followed by AZFb $(16 / 74,21.63 \%)$ and then AZFc constituted (11/74, 16.21\%), AZFab (2/ 74, $2.7 \%)$, one patient had AZFac $(1 / 74,1.35 \%)$ and four patients showed AZFabc (4/74, $5.4 \%)$. This difference may be due to ethnic background $\&$ and the low number of studied patients in their study.

It is still not clear why the AZFc deletion is so frequent, but repetitive gene clusters in this region could be a cause. Beside DAZ (Deleted in azoospermia) genes, chromodomain Y 1 (CDY1), basic protein Y 2 (BPY2), PTA-BL related Y (PRY), and testis transcript Y 2(TTY2) have repetitive sequences in the AZFc region. Intrachromosomal recombination events among these repetitive sequence blocks might lead to the abundant AZFc microdeletions ${ }^{[1]}$.

In the current work, Aall patients with AZFa (3), $\mathrm{AZFb}$ (4) and AZFbc (7) deletions are azoospermic, while $83.3 \%(26 / 31)$ of men with isolated AZFc deletion are azoospermic and $16.2 \%$ (5/ 31) are severe oligozoospermic (Table 4). These results are iIn agreement with Hopps et al. ${ }^{[66]}$ who reported thatwhereas all men with AZFa (3), AZFb (11) and AZFbc (16) deletions were azoospermic, while 26/ $42(62 \%)$ of men with isolated AZFc deletion were azoospermic. These results support that deletions in the $\mathrm{AZFa}, \mathrm{AZFb}$ or $\mathrm{AZFbc}$ regions usually lead to azoospermia and AZFc deletions lead to azoospermia or severe oligozoospermia ${ }^{[67,68]}$. We did not include a control group of normozoospermic fertile men in our study due to financial issues. However, in a study ofa previous research on Egyptian azoospermic patients, the normozoospermic fertile men had no detected AZF deletions using the same technique ${ }^{[9]}$.

Testicular volume in patients with AZF microdeletions is lower but not statistically significant than those without AZF microdeletions and both were below normal (Table 5). Other groups $[61,69,70]$ reported similar to the revealed in previous

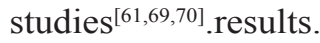

FSH level is significantly higher in patients with AZF microdeletions compared with those without (Table 5), consistent with. Mirfakhraie et al. ${ }^{[71]}$. reported the same result. In addition, other Other studies ${ }^{[61,69,72,73]}$ reported higher but not statistically significant FSH concentration in men with AZF microdeletions compared with those without microdeletions ${ }^{[61,69,72,73]}$. However, FSH values did not indicate presence or absence of spermatogenesis in cases with microdeletions ${ }^{[74]}$

Testicular volume is significantly lower and FSH and LH are significantly higher in patients with chromosomal abnormalities than those without (Table 1). These results are in agreement with A like, Koşar et al. ${ }^{[3]}$ who reported smaller testicles and higher serum FSH and LH levels in patients with chromosomal abnormalities $^{[3]}$.

Our patients with chromosomal abnormalities showed significantly lower testosterone than those without (Table 1). consistent with the findings of Zhang et al. ${ }^{[29]}$. This is The high percentage of KS $(78.3 \%)$ with lower serum testosterone among our patients with chromosomal abnormalities could explain this result.

In spite of that serum FSH, LH levels and testicular volume might have prognostic implications on testicular function ${ }^{[75]}$., In the current study, multiple stepwise logistic regression in this study could not predict either chromosomal abnormalities or AZF deletions (Table 6, 7). This is in agreement with previous the results of other studies ${ }^{[3,29]}$ who reportedreporting that $\mathrm{FSH}, \mathrm{LH}$ and testicular volume did not predict any chromosomal abnormalities ${ }^{[3,29]}$. In addition, other studies ${ }^{[75,76]}$ showed that no clinical parameter would help to identify patients with Y- chromosome microdeletions ${ }^{[75,76]}$.

\section{CONCLUSION}

We Our results emphasize the importance of karyotyping and AZF microdeletions analysis in NOA and SOZ patients. Counseling for such patients before ICSI is warranted to decrease the risk of transmitting genetic abnormalities to their offspring.

\section{CONFLICT OF INTEREST}

There are no conflicts of interest.

\section{REFERENCES}

1. Poongothai J, Gopenath TS, Manonayaki S Genetics of human male infertility. Singapore Med J 2009;50:336- 347 .

2. Dada R, Gupta NP, Kucheria K. Cytogenetic and molecular analysis of male infertility. Y chromosome deletion during nonobstructive azoospermia and 
severe oligozoospermia. Cell Biochem Biophys 2006;44:171- 177.

3. Kosar PA, Ozcelik N, Kosar A. Cytogenetic abnormalities detected in patients with non-obstructive azoospermia and severe oligozoospermia. J Assist Reprod Genet 2010;27:17- 21.

4. Al-Achkar W, Wafa A, Moassass F. Cytogenetic abnormalities and Y-chromosome microdeletions in infertile Syrian males. Biomed Rep 2013;1:275 -279.

5. Bojesen A, Gravholt $\mathrm{CH}$. Morbidity and mortality in Klinefelter syndrome $(47, \mathrm{XXY})$. Acta Paediatr 2011;100:807 -813.

6. Hotaling J, Carrell DT. Clinical genetic testing for male factor infertility: Current applications and future directions. Andrology 2014;2:339- 350.

7. Krausz C, Hoefsloot L, Simoni M, Tuttelmann F. EAA/EMQN best practice guidelines for molecular diagnosis of Y-chromosomal microdeletions. state-ofthe-art 2013. Andrology 2014;2:5- 19.

8. Elawady MK, Elshater SF, Ragaa E, Atef K, Shaheen IM, Megiud NA. Molecular study on Y chromosome microdeletions in Egyptian males with idiopathic infertility. Asian J Androl 2004;6:53- 57.

9. Fayez AG, El-Sayed AS, El-Desouky MA, Zarouk WA, Kamel AK, Fahmi IM, et al. Molecular Characterization of Some Genetic Factors Controlling Spermatogenesis in Egyptian Patients with Male Infertility. Int J Infertility Fetal Med 2012;3:69 -77.

10. Saeed H, Neamattallah H, Zaghloul T, Elmolla K. Detection of the Microdeletions on Yq Chromosome in Egyptian Population with Idiopathic Male Infertility. Life Sci J 2013;10:1191- 1199.

11. Baker K, Li J, Sabanegh E Jr. Analysis of semen parameters in male referrals. impact of reference limits, stratification by fertility categories, predictors of change, and comparison of normal semen parameters in subfertile couples. Fertil Steril 2015;103:59 -65.

12. Sakamoto $H$, Saito $K$, Oohta $M$, Inoue $K$, Ogawa Y, Yoshida H. Testicular volume measurement: comparison of ultrasonography, orchidometry, and water displacement. Urology 2007;69:152- 157.

13. Brothman AR, Persons DL, Shaffer LG. Nomenclature evolution: Changes in the ISCN from the 2005 to the 2009 edition. Cytogenet Genome Res 2009;127:1 -4.

14. Simoni M, Bakker E, Krausz C. EAA/EMQN best practice guidelines for molecular diagnosis of y-chromosomal microdeletions: State of the art 2004. Int J Androl 2004;27: 240- 249.

15. Chandley AC. The chromosomal basis of human infertility. Br Med Bull 1979;35.181- 186.

16. Tuerlings JH, de France HF, Hamers A, Hordijk R, Van Hemel JO, Hansson K,. Chromosome studies in 1792 males prior to intra-cytoplasmic sperm injection: The Dutch experience. Eur J Hum Genet 1998;6:194- 200.

17. Nakamura Y, Kitamura M, Nishimura K, Koga M, Kondoh N, Takeyama M, et al. Chromosomal variants among 1790 infertile men. Int J Urol 2001;8:49- 52.

18. Nagvenkar P, Desai K, Hinduja I, Zaveri K. Chromosomal studies in infertile men with oligozoospermia \& non-obstructive azoospermia. Indian J Med Res 2005;122:34- 42.

19. Clementini E, Palka C, Iezzi I, Stuppia L, GuancialiFranchi P, Tiboni GM. Prevalence of chromosomal abnormalities in 2078 infertile couples referred for assisted reproductive techniques. Hum Reprod 2005;20:437- 442.

20. Mohammed F, Al-Yatama F, Al-Bader M, Tayel SM, Gouda S, Naguib KK. Primary male infertility in Kuwait: A cytogenetic and molecular study of 289 infertile Kuwaiti patients. Andrologia 2007;39:87- 92.

21. Vutyavanich T, Piromlertamorn W, Sirirungsi W, Sirisukkasem S. Frequency of Y chromosome microdeletions and chromosomal abnormalities in infertile Thai men with oligozoospermia and azoospermia. Asian J Androl 2007;9:68- 75.

22. Balkan M, Tekes S, Gedik A. Cytogenetic and Y chromosome microdeletion screening studies in infertile males with Oligozoospermia and Azoospermia in Southeast Turkey. J Assist Reprod Genet 2008;25: 559- 565

23. Akgul M, Ozkinay F, Ercal D, Cogulu O, Dogan O, Altay B, et al. Cytogenetic abnormalities in 179 cases with male infertility in Western Region of Turkey. report and review. J Assist Reprod Genet 2009;26:119 -122.

24. Kumtepe Y, Beyazyurek C, Cinar C, Ozbey I, Ozkan $\mathrm{S}$, Cetinkaya K, Karlikaya G, et al. A genetic survey of 1935 Turkish men with severe male factor infertility. Reprod Biomed Online 2009;18:465- 474.

25. Ng PP, Tang MH, Lau ET, Ng LK, Ng EH, Tam PC, et al. Chromosomal anomalies and 
Y-microdeletions among Chinese subfertile men in Hong Kong. Hong Kong Med J 2009;15:31 -38.

26. Cinar C, Yazici C, Ergunsu S, Beyazyurek C, Javadova D, Saglam Y, et al. Genetic diagnosis in infertile men with numerical and constitutional sperm abnormalities. Genet Test 2008;12:195 -202.

27. Alkhalaf M,Al-Shoumer K. Cytogenetic abnormalities and azoospermia factor (AZF) microdeletions in infertile men from Kuwait. J Mol Genet Med 2010;4:232- 234.

28. Mafra FA, Christofolini DM, Bianco B, Gava MM, Glina S, Belangero SI, Barbosa CP. Chromosomal and molecular abnormalities in a group of Brazilian infertile men with severe oligozoospermia or nonobstructive azoospermia attending an infertility service. Int Braz J Urol 2011;37: 244- 250.

29. Zhang ZB, Jiang YT, Yun X, Yang X, Wang RX, Dai RL, Liu RZ. Male infertility in Northeast China. a cytogenetic study of 135 patients with non-obstructive azoospermia and severe oligozoospermia. J Assist Reprod Genet 2012;29:83 -87.

30. Fu L, Xiong DK, Ding XP, Li C, Zhang LY, Ding $\mathrm{M}$, et al. Genetic screening for chromosomal abnormalities and Y chromosome microdeletions in Chinese infertile men. J Assist Reprod Genet 2012;29: 521- 527.

31. Cavkaytar S, Batioglu S, Gunel M, Ceylaner S, Karaer A. Genetic evaluation of severe male factor infertility in Turkey: a cross-sectional study. Hum Fertil (Camb ) 2012;15:100- 106.

32. Pylyp LY, Spinenko LO, Verhoglyad NV, Zukin VD. Chromosomal abnormalities in patients with oligozoospermia and non-obstructive azoospermia. J Assist Reprod Genet 2013;30:729 -732.

33. Amouri A, Hammami W, Kilani O, Bouzouita A, Ayed W, Ben MM, et al. Chromosomal evaluation in a group of Tunisian patients with non-obstructive azoospermia and severe oligozoospermia attending a Tunisian cytogenetic department. C R Biol 2014;337: $223-228$.

34. Hofherr SE, Wiktor AE, Kipp BR, Dawson DB, Van Dyke DL. Clinical diagnostic testing for the cytogenetic and molecular causes of male infertility: the Mayo Clinic experience. J Assist Reprod Genet 2011;28:1091 -1098.

35. Vincent MC, Daudin M, De MP, Massat G, Mieusset $\mathrm{R}$, Pontonnier $\mathrm{F}$, et al. Cytogenetic investigations of infertile men with low sperm counts. a 25-year experience. J Androl 2002;23:18- 22.

36. Salahshourifar I, Gilani MAS, Masoudi NS, Gourabi H. Chromosomal abnormalities in Iranian infertile males who are candidates for assisted reproductive techniques. IJFS 2007;1: 75 -79.

37. Elghezal H, Hidar S, Braham R, Denguezli W, Ajina M, Saad A. Chromosome abnormalities in one thousand infertile males with nonobstructive sperm disorders. Fertil Steril 2006;86:1792- 1795.

38. Meza-Espinoza JP, Davalos-Rodriguez IP, Rivera-Ramirez H, Perez-Munoz S, Rivas-Solis F. Chromosomal abnormalities in patients with azoospermia in Western Mexico. Arch Androl 2006;52:87- 90 .

39. Akbari MT, Behjati F, Pourmand GR, Asbagh FA, Kachoui MA. Cytogenetic abnormalities in 222 infertile men with azoospermia and oligospermia in Iran. Report and review. Indian J Hum Genet 2012; 18:198- 203.

40. Dohle GR, Halley DJ, Van Hemel JO, van den Ouwel $\mathrm{AM}$, Pieters MH, Weber RF, et al. Genetic risk factors in infertile men with severe oligozoospermia and azoospermia. Hum Reprod 2002;17:13- 16.

41. O'Flynn O'Brien KL, Varghese AC, Agarwal A. The genetic causes of male factor infertility. a review. Fertil Steril 2010;93:1- 12.

42. Dul EC, Groen $H$, van Ravenswaaij-Arts CM, Dijkhuizen T, van Echten-Arends J, Land JA. The prevalence of chromosomal abnormalities in subgroups of infertile men. Hum Reprod 2012;27:36 -43.

43. Zhou-Cun A, Yang Y, Zhang SZ, Zhang W, Lin L. Chromosomal abnormality and $\mathrm{Y}$ chromosome microdeletion in Chinese patients with azoospermia or severe oligozoospermia. Yi Chuan Xue Bao 2006;33:111 -116.

44. Gunduz G, Luleci G, Baykara M. Cytogenetic study in 102 infertile men. Urol Int 1998;61:32- 34.

45. Carrell DT. Contributions of spermatozoa to embryogenesis. assays to evaluate their genetic and epigenetic fitness. Reprod Biomed Online 2008;16:474 -484.

46. Forabosco A, Percesepe A, Santucci S. Incidence of non-age-dependent chromosomal abnormalities: a population-based study on 88965 amniocenteses. Eur J Hum Genet 2009;17:897- 903. 
47. Van der Ven K, Montag M, Peschka B, Leygraaf J, Schwanitz G, Haidl G, et al. Combined cytogenetic and $\mathrm{Y}$ chromosome microdeletion screening in males undergoing intracytoplasmic sperm injection. Mol Hum Reprod 1997;3: 699- 704.

48. Foresta C, Ferlin A, Garolla A, Rossato M, Barbaux S, De Bortoli A. Y-chromosome deletions in idiopathic severe testiculopathies. J Clin Endocrinol Metab 1997;82:1075- 1080 .

49. Rejeb I, M'rad R, Maazoul F, Trabelsi M, Ben JL, Chaabouni $\mathrm{M}$, et al. chromosome microdeletions in Tunisian infertile males. Pathol Biol (Paris) 2008;56: 111- 115.

50. Shaqalaih AJ, Abu Halima MS, Ashour MJ, Sharif FA. Screening for Y-chromosome microdeletions in a population of infertile males in the Gaza Strip. J Exp Clin Assist Reprod 2009;6:7- 14.

51. Fu L, Xiong DK, Ding XP, Li C, Zhang LY, Ding M, Nie SS, Quan Q. Genetic screening for chromosomal abnormalities and Y chromosome microdeletions in Chinese infertile men. J Assist Reprod Genet 2012;29: $521-527$.

52. Vicdan A, Vicdan K, Gunalp S, Kence A, Akarsu C, Isik AZ, Sozen E. Genetic aspects of human male infertility. the frequency of chromosomal abnormalities and Y chromosome microdeletions in severe male factor infertility. Eur J Obstet Gynecol Reprod Biol 2004;117:49- 54.

53. Kim MJ, Choi HW, Park SY, Song IO, Seo JT, Lee HS. Molecular and cytogenetic studies of 101 infertile men with microdeletions of $\mathrm{Y}$ chromosome in 1,306 infertile Korean men. J Assist Reprod Genet 2012;29:539-546.

54. Saliminejad K, Sadeghi MR, Kamali K, Amirjannati N, Soltanghoraee H, Khorram Khorshid HR. Discrepancy in the frequency of $\mathrm{Y}$ chromosome microdeletions among Iranian infertile men with azoospermia and severe oligozoospermia. Genet Test Mol Biomarkers 2012;16: 931 -934.

55. Sen S, Pasi AR, Dada R, Shamsi MB, Modi D. $\mathrm{Y}$ chromosome microdeletions in infertile men. prevalence, phenotypes and screening markers for the Indian population. J Assist Reprod Genet 2013;30: 413- 422.

56. Lardone MC, Marengo A, Parada-Bustamante A, Cifuentes L, Piottante A, Ebensperger M, et al. Greater prevalence of Y chromosome Q1a3a haplogroup in Y-microdeleted Chilean men. a case-control study. J Assist Reprod Genet 2013;30: 531 -538.
57. Ye JJ, Ma L, Yang LJ, Wang JH, Wang YL, Guo H, et al. Partial AZFc duplications not deletions are associated with male infertility in the Yi population of Yunnan Province, China. J Zhejiang Univ Sci B 2013;14.807- 815 .

58. Ting-Ting H, Xian-Ping D, Xia W, Jing R, Li-Yuan $\mathrm{Z}$. Analysis of $\mathrm{Y}$ chromosome microdeletion in nonobstructive male infertile patients with azoospermia and severe oligozoospermia. Sichuan Da Xue Xue Bao Yi Xue Ban 2013;44: 188- 192.

59. Zhang YS, Dai RL, Wang RX, Zhang HG, Chen S, Liu RZ. Analysis of Y chromosome microdeletion in 1738 infertile men from northeastern China. Urology 2013;82: 584- 588 .

60. Hammami W, Kilani O, Ben Khelifa M, Ayed W, Abdelhak S, Bouzouita A, Zhioua F, Amouri A. Prevalence of $\mathrm{Y}$ chromosome microdeletions in infertile Tunisian men. Ann Biol Clin (Paris) 2014;72:331- 336 .

61. Ambulkar PS, Sigh R, Reddy M, Varma PS, Gupta DO, Shende MR, Pal AK. Genetic Risk of Azoospermia Factor (AZF) Microdeletions in Idiopathic Cases of Azoospermia and Oligozoospermia in Central Indian Population. J Clin Diagn Res 2014;8: 88- 91.

62. Foresta C, Ferlin A, Garolla A, Moro E, Pistorello M, Barbaux S, Rossato M. High frequency of welldefined Y-chromosome deletions in idiopathic Sertoli cell-only syndrome. Hum Reprod 1998;13: 302- 307.

63. Zhou-Cun A, Yang Y, Zhang SZ, Zhang W, Lin L. Chromosomal abnormality and Y chromosome microdeletion in Chinese patients with azoospermia or severe oligozoospermia. Yi Chuan Xue Bao 2006;33:111- 116 .

64. Jungwirth A, Giwercman A, Tournaye H, Diemer T, Kopa Z, Dohle G, Krausz C. European Association of Urology guidelines on Male Infertility. the 2012 update. Eur Urol 2012;62: 324 -332.

65. Malekasgar AM, Mombaini H. Screening of ' $Y$ ' chromosome microdeletions in Iranian infertile males. J Hum Reprod Sci 2008;1:2 -9.

66. Hopps CV, Mielnik A, Goldstein M, Palermo GD, Rosenwaks Z, Schlegel PN. Detection of sperm in men with $\mathrm{Y}$ chromosome microdeletions of the $\mathrm{AZFa}, \mathrm{AZFb}$ and $\mathrm{AZFc}$ regions. Hum Reprod 2003;18:1660 -1665.

67. Ferlin A, Moro E, Rossi A, Dallapiccola B, Foresta C. The human Y chromosome's azoospermia factor 
$\mathrm{b}(\mathrm{AZFb})$ region. sequence, structure, and deletion analysis in infertile men. J Med Genet 2003;40:18- 24.

68. Ferlin A, Arredi B, Foresta C. Genetic causes of male infertility. Reprod Toxicol 2006;22: 133- 141.

69. Peterlin B, Kunej T, Sinkovec J, Gligorievska N, Zorn B. Screening for Y chromosome microdeletions in 226 Slovenian subfertile men. Hum Reprod 2002;17: 17- 24.

70. Singh K, Raman R. Male infertility. Y-chromosome deletion and testicular aetiology in cases of azoo-/ oligospermia. Indian J Exp Biol 2005;43:1088- 1092.

71. Mirfakhraie R, Mirzajani F, Kalantar SM, Montazeri M, Salsabili N, Pourmand GR, Houshmand M. High prevalence of $\mathrm{AZFb}$ microdeletion in Iranian patients with idiopathic non-obstructive azoospermia. Indian J Med Res 2010;132:265 -270.

72. Mitra A, Dada R, Kumar R, Gupta NP, Kucheria K, GuptaSK. Screening forY-chromosomemicrodeletions in infertile Indian males. utility of simplified multiplex PCR. Indian J Med Res 2008;127:124- 132.

73. Oates RD, Silber S, Brown LG, Page DC. Clinical characterization of 42 oligospermic or azoospermic men with microdeletion of the AZFc region of the Y chromosome, and of 18 children conceived via ICSI. Hum Reprod 2002;17: 2813- 2824.

74. Abid S, Maitra A, Meherji P, Patel Z, Kadam S, Shah J, Shah R, Kulkarni V, et al. Clinical and laboratory evaluation of idiopathic male infertility in a secondary referral center in India. J Clin Lab Anal 2008;22: 29- 38 .

75. Chiang HS, Yeh SD, Wu CC, Huang BC, Tsai HJ, Fang CL. Clinical and pathological correlation of the microdeletion of $\mathrm{Y}$ chromosome for the 30 patients with azoospermia and severe oligoasthenospermia. Asian J Androl 2004;6: 369 -375.

76. Simoni M, Tuttelmann F, Gromoll J, Nieschlag E. Clinical consequences of microdeletions of the $\mathrm{Y}$ chromosome. the extended Munster experience. Reprod Biomed Online 2008;16: 289- 303. 